\title{
Interview with the Hon. Dr Michael Wooldridge: tobacco control was the best buy in health then and it's still the best buy now
}

\author{
a Former Federal Health Minister, 1996-2001 \\ b Cancer Council NSW, Sydney, Australia \\ - University of Sydney, NSW, Australia \\ d Corresponding author: paul.grogan@nswcc.org.au
}

Michael Wooldridge and Paul Grogan ${ }^{b, c, d}$

\section{Article history}

Publication date: September 2020 Citation: Wooldridge M, Grogan P. Interview with the Hon. Dr Michael Wooldridge: tobacco control was the best buy in health then and it's still the best buy now. Public Health Res Pract. 2020;30(3):e3032017. https://doi.org/10.17061/phrp3032017

\section{Key points}

- The public health community can best engage policy makers by avoiding perceptions that reforms are ideological or party-political, and making a strong, scientific-based case for funding or reform

- A key driver behind tobacco control reforms in the 1990s was the Health Minister's establishment of a group of independent experts led by an eminent scientist, which helped convince Federal Cabinet of the need to invest in new measures

- There have been significant achievements in tobacco control since the 1990s but there's not enough happening now. More investment and action is needed to reduce smoking rates further

\section{Abstract}

The late 1990s marked a turning point for tobacco control in Australia. In March 1996, the Liberal-National Coalition won government after 13 years of Labor rule. Prime Minister John Howard had campaigned on cutting expenditure, and had long been a proponent of small government and the private sector. Yet within 2 years of taking office, the Howard Government funded Australia's first big budget National Tobacco Campaign and commenced a review of the Tobacco Advertising Prohibition Act 1992 to phase out industry sponsorship of international sporting events. The Honourable Dr Michael Wooldridge, Minister for Health from 1996 to his retirement from politics in 2001, reflects on how these reforms to tobacco control were achieved and how the public health community can best engage with policy makers to advocate for reform. He stresses the importance of public health not being defined by ideology, and that politicians must be scientifically well informed and supported in doing what is in the nation's best interest for public health. He assesses the current state of play and argues more investment in tobacco control is needed today, suggesting it remains the "best buy" in health.

\section{Q: More than 23 years after the National Tobacco Campaign ${ }^{1}$ was launched, people still ask how a new health minister was able to get an unprecedented investment in tobacco control through the Prime Minister's expenditure review committee. What was your secret?}

A: I was on the expenditure review committee. It comprised the Prime Minister, who was busy with other things, the Deputy Prime Minister, the Treasurer, Assistant Treasurer and the Minister for Finance. And me - a spending minister. We'd been tasked to address the national debt. However, being medically qualified, I felt there was a strong moral obligation for the new government to also do something significant about the leading preventable cause of death and illness in the country. 


\section{Q: Moral obligations were unlikely to have been enough to cut through process - especially a tough expenditure review committee. How did you do it?}

A: I was always more interested in outcomes than process. And it wasn't just about the money. There is also the advice about how to spend it - or in some cases not to spend it. I set up an independent advisory group of expert public health professionals, led by David Hill. The group's advice was not to spend the money in the first year. It might have been wasted, without further research to make sure it was well targeted. This showed that while it was important to get the funding, it was just as important to spend it well.

A group of independent experts in their fields, led by an eminent scientist, was powerful. And their recommendation reflected their understanding of how things should work. People listen to expert advice. Being medically trained might have also assisted me in making the case.

\section{Q: Do we need more medical doctors in public health to engage conservative policy makers?}

A: I think the main challenge is to avoid having issues defined in political terms. The public health community could do a lot better at recognising that public health is not ideological.

There are exceptions. Michael Moore [former CEO of the Public Health Association] got it. He had been a centre-left politician and an independent health minister in a minority centre-right government in the ACT. But he didn't come across as left or right. There were a few others around at that time too. Alan Coates [former CEO, Cancer Council Australia], David Hill [former director, Cancer Council Victoria] of course. Steve Woodward [former executive director, Action on Smoking and Health]. Stephen Leeder [former Dean of the Medical Faculty, University of Sydney]. I never had any sense of their personal political views. It was never an issue. The focus was on what we could achieve.

But as a sector, the public health community would be more successful if it avoided perceptions that reforms and the discussions about them are party-political. It can play out in media in that way too.

\section{Q: Yet the perception remains that public health and the nanny state are ideological?}

A: That perception doesn't reflect how things work. It's critical for public health not to be defined by ideology. Australia was one of the more successful countries at controlling HIV infection, because of the nonpartisan goodwill between Peter Baume [physician, Federal Liberal Senator, 1974-1991] and Neal Blewett [Federal Minister for Health, 1983-1990]. They recognised it was in the nation's interest to take the politics out of HIV control which was the position when I came in as Health Minister in 1996.
Yet when we took office, not many in the public health community expected a new centre-right government to do much in tobacco control. That might have been why I was criticised for deferring the campaign. The decision was based on independent expert advice, yet I was still taken to task in the media. To get big things done in government requires the acquiescence of one's Cabinet room colleagues. Trying to lead in an area like tobacco control, being guided by independent expert advice, and still being criticised for it is unhelpful.

That said, things have improved. The Public Health Association organised a good event in Parliament House last year to celebrate achievements from both sides of politics. It helped to show that public health is not ideological. The key is making a strong case for funding or reform.

\section{Q: A major reform in your time was the amendment of the Tobacco Advertising Prohibition Act $1992^{2}$ to phase out industry sponsorship of international sporting events. How did that come about?}

A: That is an example of the importance of being strategic. The reforms which were eventually covered by the amended Tobacco Advertising Prohibition Act ${ }^{2}$ in 2000 were a world first. To get it through, I had to show my colleagues I was engaging widely, in Australia and internationally. This included engaging with the tobacco industry. Things are very different now, but back then, one in four Australian adults smoked, and the industry had a much stronger influence everywhere. The industry said it wanted predictability. So, I was direct and said: "My job is to manage your product down in Australia". That was the certainty I gave them. It took 3 years to do what I thought was necessary to get the Act amendments up. It then became impossible for a lot of other countries not to do it. Outside government it might not seem difficult, but Australia is a federation, the Victorian Government had a major stake in the Melbourne Grand Prix, the industry had its hooks into state governments in ways that it no longer does. It was a different world. We reduced the industry's influence by amending the Act, having already sought to marginalise them with the campaign. The outcome was what mattered.

\section{Q: What was the key to getting the amendments through?}

A: I had important allies, not all of whom would be obvious. A good example is Ian McLachlan. A country MP, farmer and a former Sheffield Shield cricketer. He understood tobacco industry sports sponsorship. He appreciated what I was trying to do, when I explained the need for certainty, and he was supportive in Cabinet. It's another example of why we shouldn't be doctrinaire or make assumptions about public health along ideological or personal lines.

I also tried to be scientific. Politics is about who did what to whom. I focused on organisational behaviour rather than politics and engaged with people like Bernie 
Ecclestone [former CEO, Formula One Group], to provide a sense of where this was going. In the 1990s, this was important. I had to show my Cabinet colleagues that I'd engaged and that we could get a result. And we did.

\section{Q: What are your thoughts on the current state of tobacco control compared with the 1990s?}

A: Nicola Roxon [Former Federal Labor MP and Minister for Health and Ageing, 2007-2011] did something substantial in introducing plain packaging. While I certainly considered it, I don't think I would have been able to get that through in the 1990s, only because there would have been grave concerns about intellectual property. I congratulate Nicola for getting it through, and successive Coalition Governments since 2013 for continuing their strong commitment to supporting the legislation in international trade disputes. The World Trade Organization's (WTO's) recent reaffirmation of an earlier ruling that the plain packaging laws were consistent with WTO rules was a great moment in bipartisan public health policy - and a great moment in Australian global leadership.

Plain packaging also facilitated a substantial increase in tobacco tax, which has reduced smoking rates and enjoyed strong bipartisan support. Tobacco excise and customs duty taxes were also increased substantially when I was in Cabinet. I think it's also important to recognise the role of Peter Costello [former Federal Liberal MP and Treasurer, 1996-2007] in being the first treasurer to tax cigarettes on a per-stick basis. We were on track for huge pack sizes, which would have hurt disadvantaged populations. The current Federal Health Minister, Greg Hunt, should be supported for taking a strong line against vaping.

Otherwise, there's not enough happening. We can't be complacent about tobacco control.

\section{Q: Federal Health Minister Greg Hunt has committed} $\$ 20$ million over 3 years to revive the National Tobacco Campaign $^{3}$ and recently doubled the 2020 allocation to $\$ 10$ million, recommitting to his tobacco control plan when the COVID-19 pandemic emergency eases. How can public health work with government to do more?

A: For Greg Hunt to increase the funding, he'll have to find the money somewhere. That's how it works. I expect he'll bring in independent expert advice, like I did. It's an opportunity for the public health sector. And this goes to the most important point of all. About $98 \%$ of political activity is directed at making politicians feel bad and only $2 \%$ is focused on making them feel good. Like any minister, Greg would have to make tough decisions to find new funds and increase expenditure. People go into public office because they want to contribute, and to feel good about it - like anyone. The most successful community advocates are the ones who know how to make politicians feel good. That's the message for the public health community.

\section{Q: Will it be harder in today's political climate for the Commonwealth to secure the intergovernmental coordination of the original National Tobacco Campaign?}

A: It should be easier, because of what we did, back then and subsequently. We neutralised the tobacco industry, which was always much more active at state level, by reducing its market and eliminating its influence in sports sponsorship.

\section{Q: You mentioned complacency. When can we take the foot off the pedal on tobacco control?}

A: When adult smoking rates are $2 \%$ or lower. To get there, we need more of what works. And in areas where the evidence is less clear, such as interventions for disadvantaged populations, the use of social media and targeted approaches, we need more research.

\section{Q: What's the take-home message to today's politicians?}

A: Tobacco control was the best buy in health back then and it's still the best buy now. I understand some resistance to investing in preventive health, when the returns can take a long time to accrue. This is why you need political support. But it should also be remembered that the original National Tobacco Campaign started to pay for itself within a year. It's an outstanding investment.

\section{Peer review and provenance}

Internally peer reviewed, invited.

\section{Competing interests}

MW is a consultant for the Strategic Counsel, which is listed on the Australian Government Register of Lobbyists. The company's clients do not include any tobacco-related products such as nicotine-dependence treatment or e-cigarettes. PG was a media/parliamentary liaison officer in MW's department throughout MW's time as Health Minister.

\section{Author contributions}

PG conducted the interview with MW and prepared the manuscript. 


\section{References}

1. Australian Government Department of Health. National Tobacco Campaign. Canberra; Australian Government; updated July 2020 [cited 2020 Jul 27]. Available from: www.health.gov.au/initiatives-and-programs/nationaltobacco-campaign

2. Australian Government. Federal Register of Legislation. Tobacco Advertising Prohibition Act 1992. Canberra: Australian Government; amended July 2016 [cited 2020 Jul 27]. Available from: www.legislation.gov.au/Details/ C2016C00899

3. The Hon Greg Hunt MP. Ministers. Department of Health. Media release: four times as many people trying to quit smoking during COVID-19. Canberra: Department of Health; 2020 May 31 [cited 2020 Jul 27]. Available from: www.health.gov.au/ministers/the-hon-greg-hunt-mp/ media/four-times-as-many-people-trying-to-quit-smokingduring-covid-19

\section{Copyright: (c) (i) (5)}

(c) 2020 Wooldridge and Grogan. This article is licensed under the Creative Commons Attribution-NonCommercial-ShareAlike 4.0 International Licence, which allows others to redistribute, adapt and share this work non-commercially provided they attribute the work and any adapted version of it is distributed under the same Creative Commons licence terms. See: www.creativecommons.org/licenses/by-nc-sa/4.0/ 